\title{
KLKB1 wt Allele
}

National Cancer Institute

\section{Source}

National Cancer Institute. KLKB1 wt Allele. NCI Thesaurus. Code C95566.

Human KLKB1 wild-type allele is located in the vicinity of $4 q 35$ and is approximately $49 \mathrm{~kb}$ in length. This allele, which encodes plasma kallikrein protein, is involved in the regulation of proteolysis, blood coagulation, fibrinolysis and inflammation. Mutation of the gene is associated with a blood coagulation disorder arising from prekallikrein deficiency. 